\title{
Brief Notes on Geodiversity and Geoheritage Perception by the Lay Public
}

\author{
Lucie Kubalíková $^{1, *}$, Aleš Bajer ${ }^{2}$ and Marie Balková ${ }^{2}$ (D) \\ 1 Institute of Geonics of the Czech Academy of Sciences, Drobného 28, 60200 Brno, Czech Republic \\ 2 Department of Geology and Soil Science, Faculty of Forestry and Wood Technology, Mendel University in \\ Brno, Zemědělská 3, 61300 Brno, Czech Republic; bajer@mendelu.cz (A.B.); \\ marie.balkova@mendelu.cz (M.B.) \\ * Correspondence: Lucie.Kubalikova@ugn.cas.cz
}

check for updates

Citation: Kubalíková, L.; Bajer, A.; Balková, M. Brief Notes on Geodiversity and Geoheritage Perception by the Lay Public. Geosciences 2021, 11, 54. https: / / doi.org/10.3390/ geosciences 11020054

Received: 18 January 2021

Accepted: 26 January 2021

Published: 28 January 2021

Publisher's Note: MDPI stays neutral with regard to jurisdictional claims in published maps and institutional affiliations.

Copyright: (c) 2021 by the authors. Licensee MDPI, Basel, Switzerland. This article is an open access article distributed under the terms and conditions of the Creative Commons Attribution (CC BY) license (https:// creativecommons.org/licenses/by/ $4.0 /)$.

\begin{abstract}
Geodiversity has an irreplaceable significance for both biodiversity and for human society as it has numerous functions and offers various benefits and services. These have been already recognized and assessed by using numerous approaches and methods (e.g., geosite assessment methods, geodiversity indexes, and evaluation of geodiversity functions within the concept of ecosystem services). Nearly all these procedures were elaborated by professionals in the Earth sciences or related domains. The assessment of geodiversity functions and services within nature conservation by the public was not the subject of detailed research yet (with an exception of geotourist assessment). This communication presents the results of a pilot research that is focused on the analysis and interpretation of the public opinion on geodiversity and geoconservation. The data were collected by using the semi-structured questionnaire, and based on them, the interpretation was done and comparison or confrontation with original hypotheses was undertaken.
\end{abstract}

Keywords: geoconservation; geodiversity; natural heritage; public; perception; conflict of interest

\section{Introduction}

Geodiversity (defined by Gray [1] as the natural range (diversity) of geological, geomorphological, soil and hydrological features, including their assemblages, structures, systems and contribution to landscapes) has an irreplaceable significance for both the biodiversity [2-5] and for human society, especially for understanding the history of Earth, for its cultural/historical values [6] or as a resource for tourism and recreation [7-9]. The functions, services, and benefits of geodiversity have already been recognized [1,10-12] and assessed by using numerous methods and approaches including the concept of ecosystem services [10,13-17]. Particular methods for assessing the geological and geomorphological sites were also introduced (for a critical overview of the methods see, e.g., References [18-22]), especially within the context of geoheritage management and geoconservation. Geodiversity was also a subject of quantitative and statistical assessment by creating and using geodiversity or geomorphodiversity indexes [4,23-27].

These procedures were mainly elaborated by professionals/experts in geosciences or related branches and they are used as an effective tool for implementing the conservation policies or included into the regional or local planning $[11,13,16,28]$.

The use of sociological methods in geodiversity and geoconservation research is not as common as in geotourism studies [29-34]. Nevertheless, there are studies focused on the perception of environmental changes [35], community perceptions for geoconservation [36] or the local community perception of selected geomorphosites [37]. The last mentioned paper also states that perception studies concerning the evaluation of geoheritage are essential for the land management and environmental policies and that the analysis of the perception may support the implementation of geoheritage preservation and management measures [37]. 
This communication presents the results of a pilot study focused on the simple assessment of geodiversity importance and on the perception of geoconservation needs. The aim of this pilot survey was to find the answer to the following questions:

(1) Does the public recognize geodiversity importance?

(2) Is the public aware of the need for geoconservation?

(3) Which sites would public include in the natural heritage (geoheritage)?

(4) What are the main factors influencing tourist choice?

(5) Which sites/localities are preferred as a tourist destination?

Based on this, and before the survey itself, four hypotheses were formed: (1) the public accepts the nature conservation in general, but puts a higher emphasis on conservation and protection of living nature, (2) the public prefers to visit abiotic components of nature (e.g., significant or aesthetically valuable landforms) instead of "strictly biotic" sites, (3) public would include into the natural heritage mostly aesthetically significant sites (e.g., caves, mountains or remarkable outcrops), (4) the main factors influencing the visitor's choice are aesthetic aspect, accessibility/safety, and uniqueness. The results of the survey are then confronted with these hypotheses.

\section{Materials and Methods}

The respondents were addressed personally in an abandoned limestone quarry of Hády, situated on the northern border of the Brno city. The quarry has been appropriately restored and its geoheritage values were conserved. The area is currently used for ecotourism and geotourism activities, geoeducational purposes, short-term recreation, and walking/hiking and it serves as a traditional leisure or tourist destination for both people from the city and visitors (see Figure 1).

Geologically, the area is built of crystalline rocks of Brno massif, Devonian sedimentary rocks, and Jurassic limestone. In the lower part of the Hády quarry (Růženin lom), the tectonic thrust of the older rocks of Brno Massif on the younger Upper-Devonian and Lower-Carbon limestones of the Líšeň formation can be observed. Additionally, the alternation of limestone, clay limestone and calcic claystone is visible, together with other facies that reflect the turbulent sedimentation [38]. In the upper bench of the Hády quarry, the uncomformity of the Jurassic limestones and the folded Devonian limestones can be seen. The Jurassic limestones are paleontologically rich: ammonites, belemnites, crinoids, brachiopods and sporadically shark teeth can be found here [39]. The original relief of the area is strongly influenced by human activity, especially quarrying. Since the Middle Ages, there were small limestone quarries on the upper plain. Currently, these landforms are not so distinctive and can be confused with natural landforms (especially sinkholes). Since the 1960s, the limestone was extracted intensively and the original slope practically disappeared. However, when the quarrying has been finished, the area was successfully restored and parts of it became legally protected within the lowest category of general nature protection- “Important Landscape Element" and the lowest category of territorial nature protection-“"Natural Monument" [40].

Concerning the anthropogenically conditioned processes, it is possible to observe the formation of debris cones (both in the lower and upper part of the quarry), which has a remarkable geoeducational potential. The bottom of the quarry is flooded by a lake important from the ecological point of view; halophytes and steppe species can be found here. The site is well accessible; there are several marked paths in the area and an educational trail about the natural features. The site is also widely used as an excursion locality for university students. This complex of anthropogenic landforms is a good example of how the overall geodiversity and biodiversity can be increased by human action and how the anthropogenic landforms can serve educational and recreational purposes. Close to this area, a new recreational zone is proposed-it should have the character of a park (according to the land-use plan of the Brno city) with the possibility of sports activities. 


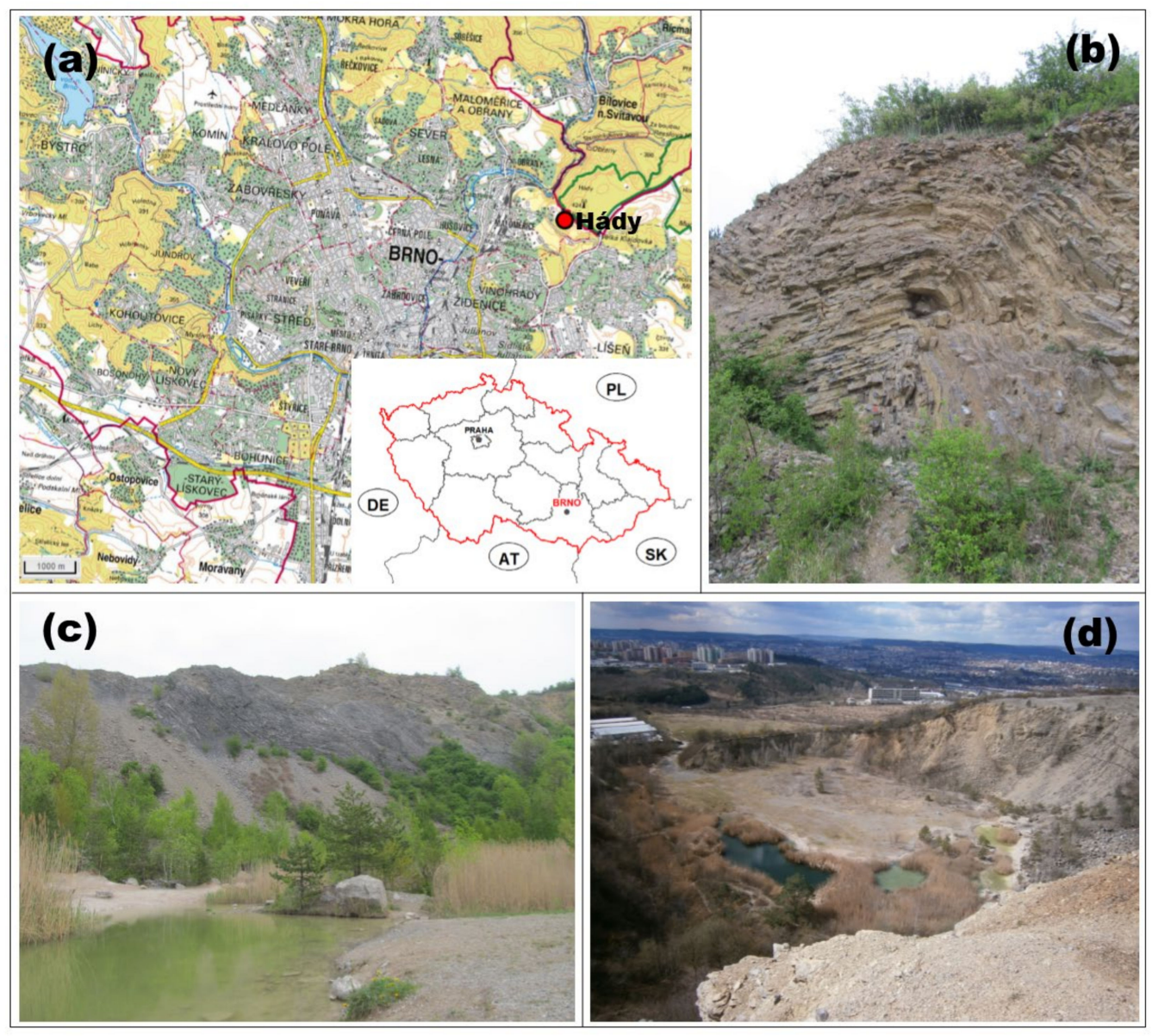

Figure 1. The area of collecting the data: abandoned limestone quarry of Hády (a) — position within the Brno city, (b)-limestone folds on the upper bench, (c)-lake on the bottom of the quarry, and (d)-a view from the upper bench. Photo: authors.

The visitors to this area were the target group of the survey. The sample of respondents was random, not considering socio-economic and demographic aspects such as gender, income, education level, and occupation. In total, 51 respondents were interviewed, 58\% were women and $42 \%$ men. The age structure was the following: up to 20 years: $4 \%$, 21-30 years: 39\%, 31-40: 22\%, 41-50: 20\%, 51-60: 10\%, 61 and older: 6\%. Regarding education, the structure was the following: $8 \%$ respondents with primary education, $55 \%$ respondents with secondary education and $37 \%$ respondents with higher education.

The questionnaire covered four groups of questions: (1) recognition of geodiversity, geoconservation need and their importance, (2) geoheritage, (3) visitor's preferences, (4) geotourism aspects of geodiversity (factors that can influence the decision making of visitors). There was a group of closed questions (yes/no/I don't know). For the evaluation of geodiversity functions and services, a Likert scale was used [41] — for every criterion, a value $1-5$ was attributed. Some questions used pictures-it was supposed that the use of illustrations could help to surpass the lack of scientific knowledge of the respondents about the landforms [37]. There was also a space for expressing own opinion, which was not covered by any question or the possibility to add any comment to the questions containing pictures.

\section{Results}

The first group of questions was focused on geodiversity importance and geoconservation need. While some of the questions were verbal and closed (e.g., knowledge of geodiversity, opinion on the need of geoconservation, the sufficiency of geoconservation measures) or open (the legal tools of nature protection intended for geoconservation), other 
questions were accompanied by pictures, which could help to overcome the problems with explications. The following pictures were presented: (1) plant, (2) rocky landform (tor), (3) mammal, (4) fossil, (5) insect, (6) abandoned quarry, (7) karst cave, and (8) river.

The term "geodiversity" is unknown to approx. $25 \%$ of respondents; over $40 \%$ of respondents know the term and are able to explain it. The rest of respondents (35\%) have heard the term, but they do not know its exact meaning. 95\% of respondents agree that geodiversity should be protected, however, the respondents prefer the protection of living nature (plants, mammals and insects); concerning abiotic nature, the karst features are considered as the most worthy of protection and conservation. $63 \%$ of respondents state that the geoconservation is not sufficient and that it should be supported somehow. Approximately half of the respondents state that they know some legislative tools for the geoconservation; they usually gave the examples as "Natural Monuments", "National Parks" and "Geoparks". Only a few of them mentioned lower categories of nature protection (which are also applicable to geosites) - Important Landscape Element or Natural Park, which (according to Act n. 114/1992 Coll. [42]) protect the landscape appearance. No respondent mentioned the general protection of the caves, fossils and mineral deposits defined in Act n. 114/1992 Coll. and included in the general nature conservation. The detailed results are presented in Figure 2.

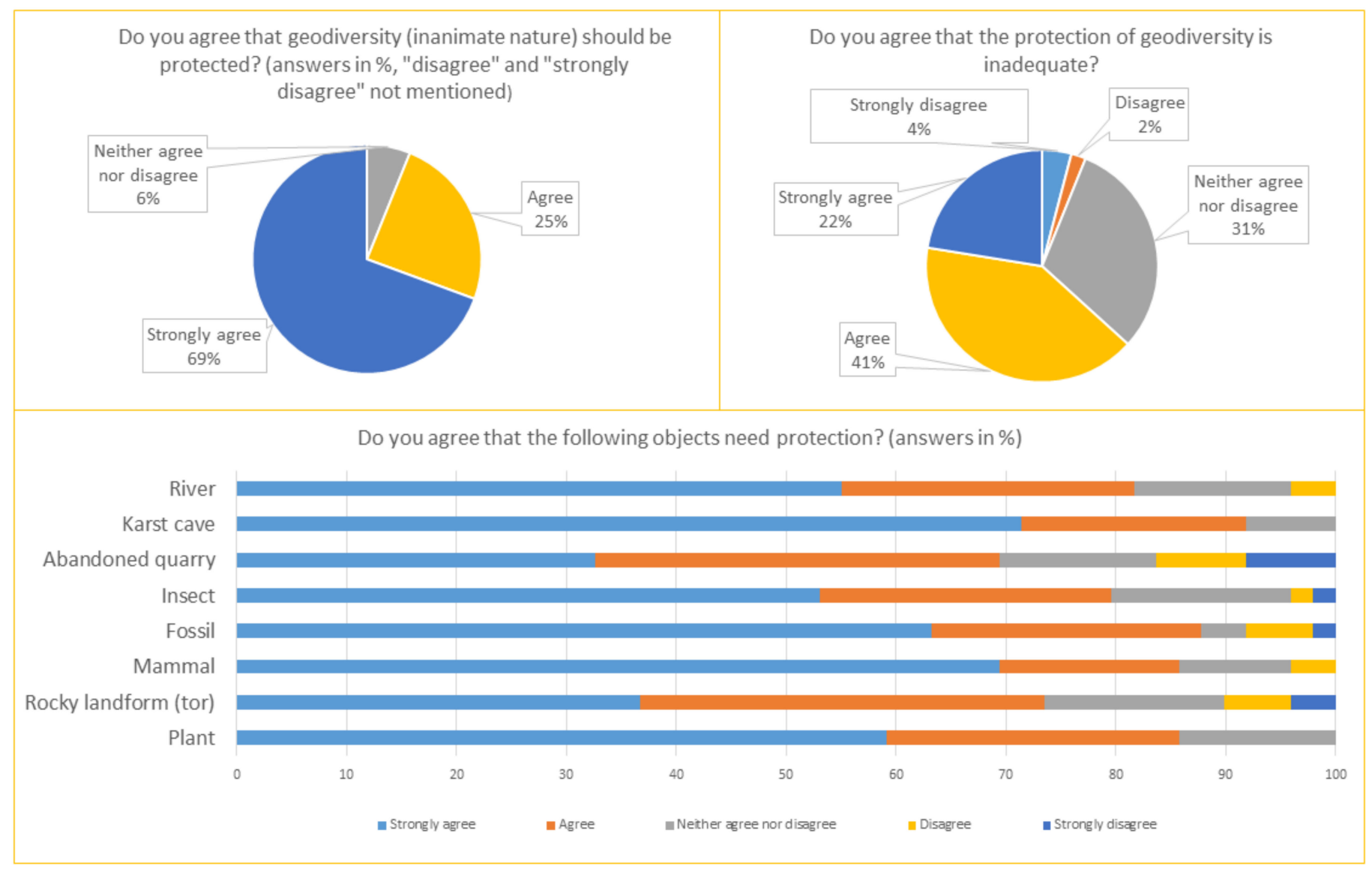

Figure 2. The results of the first group of questions. The differences between the need of protection for particular objects; there is a remarkable difference in opinion on the protection of abiotic nature-in some cases the abiotic components of the nature are not estimated as those that need the protection.

The second part of the questionnaire was focused on natural heritage, geoheritage, and potential geoheritage sites. $94 \%$ of respondents say that they have heard the term "natural heritage" and 75\% of respondents are able to clarify the term. Only $6 \%$ have never heard this term or do not absolutely know what it is. Based on the pictures (erratic boulder, 
blockfield, sandstone rock city, abandoned quarry with columnar basalt jointing, limestone cliffs, abandoned quarry with folds, karst cave, and river valley), respondents decided that rather aesthetically attractive geodiversity sites should be included in the "natural heritage" (e.g., sandstone rocks, karst caves, and columnar jointing of basalts). The rivers, quarries or erratic boulders are not very often included in the natural heritage. For detailed results, see Figure 3.

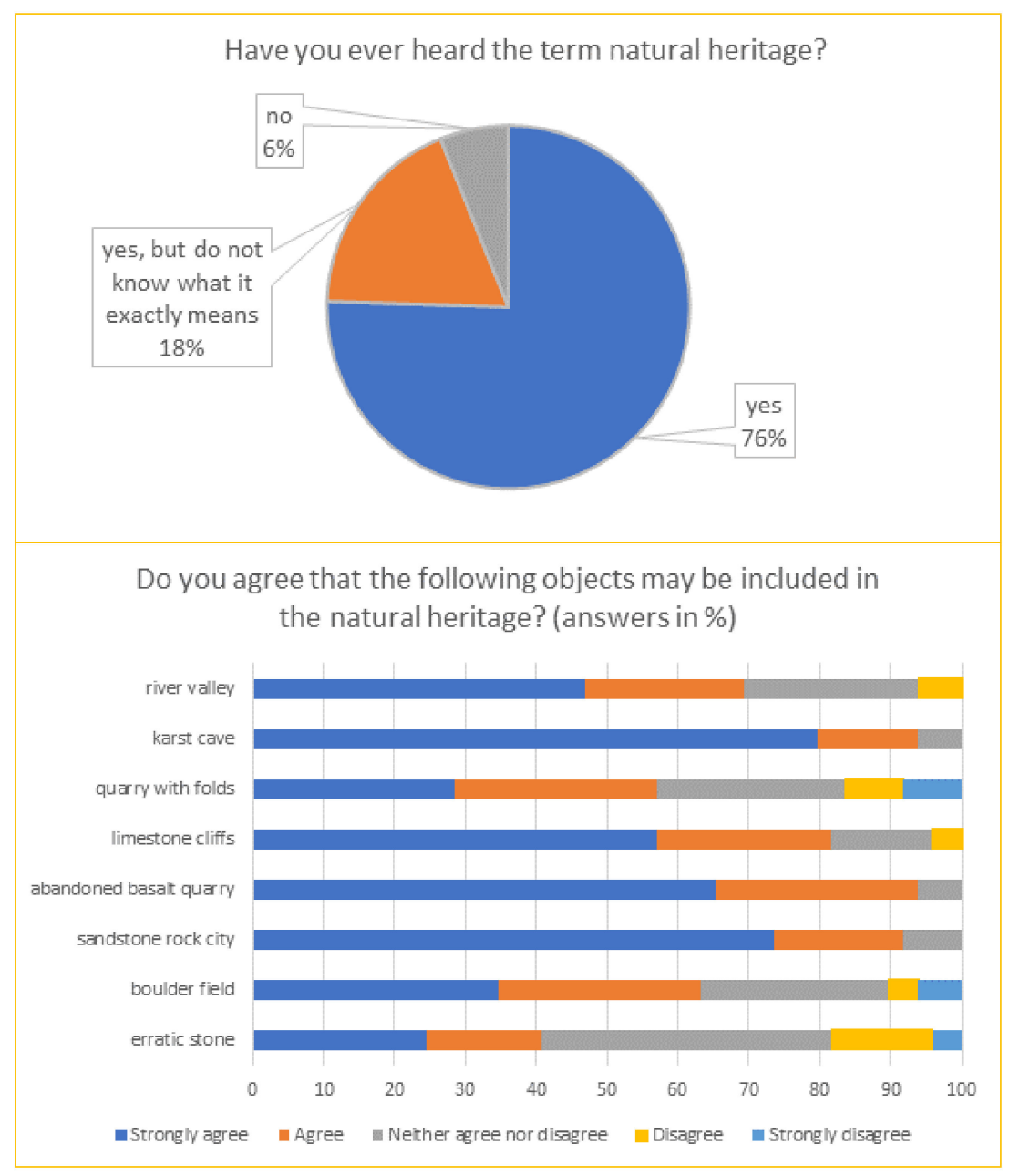

Figure 3. According to the survey, the karst caves and sandstone rock cities are those that deserve protection and inclusion into the natural heritage.

The third part of the questionnaire included a set of pictures that represented potential tourist destinations situated in the Czech Republic. All were natural, some of them included mainly the abiotic nature elements, some of them displayed biological sites, and some of them represented both aspects. They were the following: (1) a biological site with important flora, (2) blockfield with frost-riven cliffs, (3) mountain meadow with scattered conifer trees, (4) abandoned quarry with columnar basalt jointing, (5) beech forests, (6) limestone cliffs without trees surrounded by steppe vegetation, (7) karst caves, and (8) river valley with floodplain forest. The visit preferences of the public were not determined. However, the karst cave, aesthetically valuable basalt quarry and limestone cliffs slightly prevail. For detailed results, see Figure 4. 


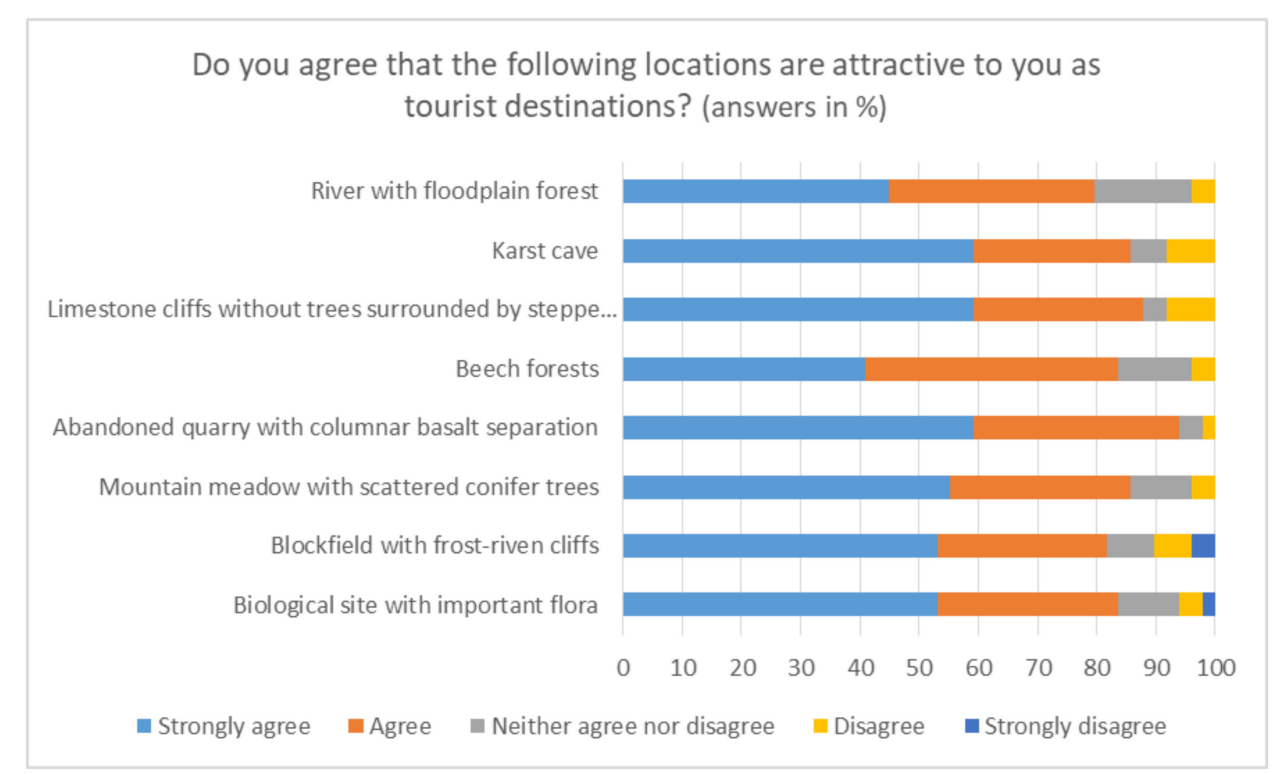

Figure 4. The results of the third group of questions: there are no big differences between the choice of destinations.

The last section was focused on the factors or criteria that may affect the tourist's or visitor's choice. For the assessment, the following factors were considered: (1) aesthetics of the site, (2) uniqueness, (3) the proximity to the place of living, (4) accessibility, difficulty of the terrain, (5) safety, (6) entrance fees, (7) legislative protection of the site, (8) presence of the tourist infrastructure, (9) the number of visitors to the site, and (10) possibility of obtaining any knowledge on the site.

The most important factors are the aesthetics of the locality and its uniqueness. Surprisingly, the possibility to get information about the site and the number of visits also play an important role. The less important factors are the presence of tourist infrastructure, entrance fees and proximity of the residence. The detailed results are presented in Figure 5.

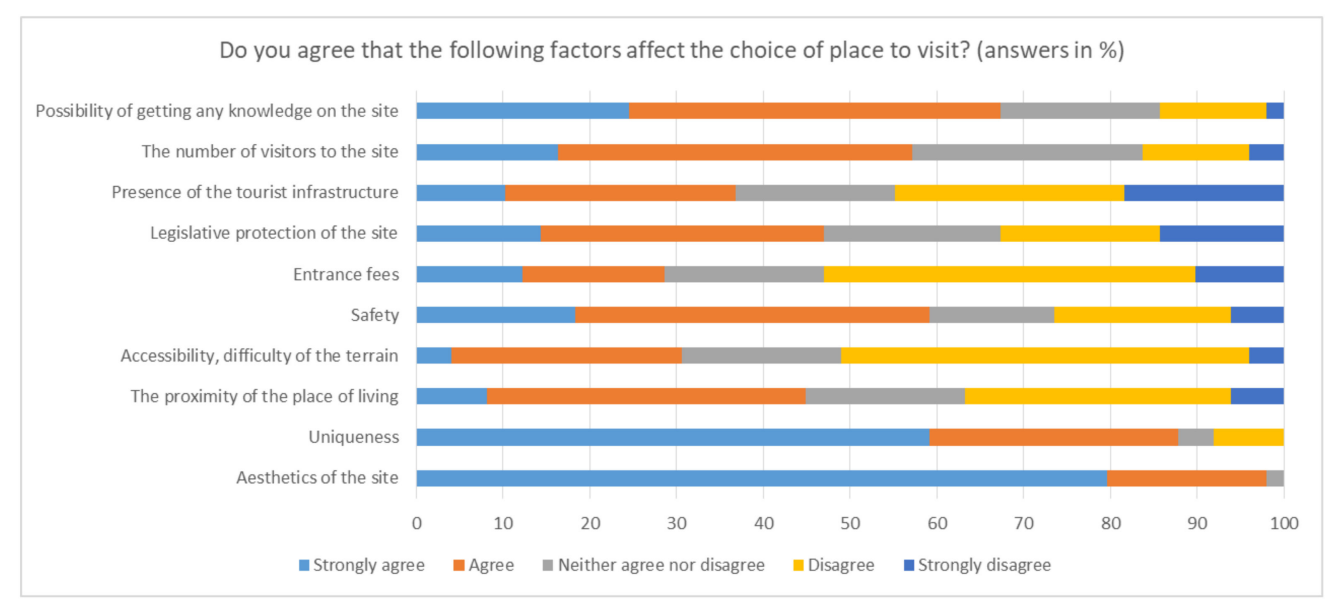

Figure 5. The results of the fourth group of questions: the aesthetics of the site is the most important factor that influences the visitor's choice.

\section{Discussion}

The results from the first part of the questionnaire confirm the hypothesis that the public accepts nature protection. The majority of respondents believe that geological and geomorphological components deserve protection. Nevertheless, for the public, it is still more important to protect living nature (see results in Figure 2). This is probably due to the following factors: (1) within the nature conservation in general, an emphasis has 
been placed on living nature for a long time and geodiversity has been neglected [43-45]. This can be reflected in public attitudes, as there is a popular belief that it is necessary to take care of vegetation cover and animals and that rocks protect themselves because they are indestructible [46]; (2) in some cases, inanimate nature is erroneously considered as something unchangeable because the rate of change processes in the abiotic environment is much lower than the speed changes in populations or areas of distribution of living organisms, or geological time is incomparably slower than biological time [3,46,47].

At the same time, it is clear that the loss of geodiversity has occurred (since the late Middle Ages-mining, crushing of rocks for the purpose of navigating rivers, changes in river bed morphology, etc.), and in some cases, the intensity of anthropogenic processes is much higher than the intensity of natural processes [48]. Geodiversity is significantly endangered by these activities $[36,46,49,50]$, which is reflected in changes in landscape character and eventually in changes in biodiversity. These human-induced changes then have a reciprocal effect on other human activities [48].

The results of this part of the questionnaire can serve as an argument for further developing and supporting geodiversity and geological heritage education programs and for projects aimed at promoting the importance of geodiversity in general.

Regarding the second hypothesis (incorporating specific objects into the natural heritage), the results have shown that the public indeed chooses the aesthetically interesting sites to be included in natural heritage, probably regardless of their scientific value. While the site's aesthetics is important in terms of geotourism and recreation, in most cases it is not the main criterion when deciding to include a site in natural heritage and subsequent proposals for legislative protection [19,51]. However, UNESCO [52] includes natural aesthetic components among the objects of natural heritage ("natural features of physical and biological formations, which are outstanding universal value from the aesthetic or scientific point of view"). This document operates with the term "natural beauty", which, however, is never defined. In most cases, the methods for assessing geosites for the management of natural heritage (geoheritage) take into account the aesthetic aspect, e.g., References [51,53] evaluate the aesthetics of the site based on color contrasts or space structuring, but this value still remains very subjective and partially ungraspable. The public probably takes into account similar criteria (shape diversity, color, contrasts, and expressiveness) and gives them more weight than the scientific or intrinsic values of the site. This may be because public is not sufficiently aware of the scientific value of geosites. This result can also serve as an argument for promoting awareness-raising activities on the importance of geodiversity within natural heritage (e.g., through geological nature trails).

The third hypothesis (the public prefers to visit the abiotic components of nature) was only confirmed partially - the preferences of the visitors were not clear. The most attractive for visitors was the karst cave, which may be due to the fact that the caves have always been a traditional destination in the Czech Republic [54]. However, the differences in the assessment of sites as an attractive tourist destination were not significant. Regarding the results on site preferences, no anticipated discrepancy was found between "protection needs" and "visitor preferences". The preference hypothesis was intended as an interesting paradox: while in the field of nature conservation, the public prefers to protect the living component, in the area of tourism preference is given to sites with a distinctive element of inanimate nature (e.g., rock formation). This paradox was based on the works of Gray [1] and Dowling and Newsome eds. [8]. However, the investigation did not reveal the facts that would confirm these claims.

The last hypothesis concerning factors influencing the choice of geotourism site was based on the works of Allan [29], Mao et al. [55], Ruban et al. [56], Kirillova et al. [57], Dowling [58], Štrba et al. [32] and Štrba [34]. For example, Štrba [34] states that the most significant influence is the visual attractiveness of the site (here the aesthetics of the site), accessibility/safety of the site and its uniqueness. However, the target group in this survey were potential visitors, not visitors surveyed at the sites. Based on our investigation, it was found that aesthetics plays an important role, but the criterion of the uniqueness of the site 
exceeded access and safety. The discrepancy between the findings of Štrba [34] regarding the possibility of obtaining information about the locality is interesting (possibility to learn something) - this criterion is ranked at the penultimate place (the last one is the number of tourists on the site), while in our study, this criterion is one of the top ones. Site accessibility and safety have not been evaluated as high as in the mentioned study. Again, it is possible that the difference is given by a different target group. Additionally, the importance of safety as a factor influencing the choice of geotourism site corresponds to the findings presented in Reference [56] and eventually to Grant's typology of geotourists [58].

\section{Conclusions}

The results of the study confirmed the hypotheses especially in the field of the conservation of abiotic nature and natural heritage. On the basis of these, it can be stated that, while the protection of geoheritage is accepted, it is still being overlooked in comparison to the protection of the living nature. Activities aimed at promoting geodiversity in general (both in rural and urban areas) and raising awareness of geodiversity as an important part of the natural heritage could improve the situation. All this can lead to a better acceptance of the proposed measures within the territorial and general protection of nature and landscape, including the protection of geological elements and phenomena. At the same time, the results are partly usable in planning and strategic documents.

The study is considered to be a pilot study both in terms of its scope and the target group definition. In order to find out what opinion the general public has on the protection of abiotic nature or how it evaluates related geotourist aspects, more respondents would be needed whose structure would correspond to the demographic structure of the current population. One of the limitations of this study is that it reflects the opinion of the small dataset of the Czech public with a relatively good level of education. The positive thinking about nature conservation can be caused by the fact that the age structure mainly involved younger respondents. However, the results of this study are applicable to local development strategies and can provide arguments for financial support for activities related to education, promotion and the future rational use of geodiversity.

Author Contributions: Conceptualization, resources, methodology, investigation, data curation, writing-Original draft preparation, writing-Review and editing: L.K.; resources, methodology, investigation, data curation, writing-Review and editing: A.B., investigation, resources, data curation: M.B. All authors have read and agreed to the published version of the manuscript.

Funding: This research was supported by project n. TL02000219 “Geodiversity within urban areas: perception, function, potential” (Geodiverzita v rámci města: percepce, funkce, potenciál) funded by Technology Agency of the Czech Republic (ETA programme).

Informed Consent Statement: Informed consent was obtained from all subjects involved in the study.

Data Availability Statement: The data are not publicly available due to restrictions.

Conflicts of Interest: The authors declare no conflict of interest.

\section{References}

1. Gray, M. Geodiversity: Valuing and Conserving Abiotic Nature, 2nd ed.; Wiley-Blackwell: Chichester, UK, 2013.

2. Nichols, W.F.; Killingbeck, K.T.; August, P.V. The influence of geomorphological heterogeneity on biodiversity II: A landscape perspective. Conserv. Biol. 1998, 12, 371-379. [CrossRef]

3. Santucci, V.L. Historical perspectives on biodiversity and geodiversity. George Wright Forum Geodivrs. Geoconserv. 2005, 22, 29-34.

4. Hjort, J.; Gordon, J.E.; Gray, M.; Hunter, M.L. Why geodiversity matters in valuing nature's stage. Conserv. Biol. 2015, 29, 630-639. [CrossRef]

5. Tukiainen, H.; Alahuhta, J.; Field, R.; Ala-Hulkko, T.; Lampinen, R.; Hjort, J. Spatial relationship between biodiversity and geodiversity across a gradient of land-use intensity in high-latitude landscapes. Landsc. Ecol. 2017, 32, 1049-1063. [CrossRef]

6. Gordon, J.E. Geoheritage, geotourism and the cultural landscape: Enhancing the visitor experience and promoting geoconservation. Geosciences 2018, 8, 136. [CrossRef] 
7. Reynard, E.; Holzmann, C.; Guex, D. Géomorphologie et tourisme: Quelles relations? In Géomorphologie et tourisme, Actes de la Réunion annuelle de la Société Suisse de Géomorphologie (SSGm) Finhaut, Switzerland 21-23 September 2001; Reynard, E., Holzmann, C., Guex, D., Summermatter, N., Eds.; Institut de Géographie: Lausanne, Switzerland, 2003; Volume 24, pp. 1-10.

8. Newsome, D.; Dowling, R. Geotourism: The Tourism of Geology and Landscape; Goodfellow Pub Ltd.: Woodeaton, Oxford, UK, 2010.

9. Dowling, R.K.; Newsome, D. Handbook of Geotourism; Edward Elgar Publishing: Camberley, UK, 2018.

10. Gray, M. The confused position of the geosciences within the "natural capital" and "ecosystem services" approaches. Ecosyst. Serv. 2018, 34, 106-112. [CrossRef]

11. Brilha, J.; Gray, M.; Pereira, D.I.; Pereira, P. Geodiversity: An integrative review as a contribution to the sustainable management of the whole of nature. Environ. Sci. Policy 2018, 86, 19-28. [CrossRef]

12. van Ree, C.C.D.F.; van Beukering, P.J.H. Geosystem services: A concept in support of sustainable development of the subsurface. Ecosyst. Serv. 2016, 20, 30-36. [CrossRef]

13. Gordon, J.E.; Barron, H.F. Valuing geodiversity and geoconservation: Developing a more strategic ecosystem approach. Scott. Geogr. J. 2012, 128, 278-297. [CrossRef]

14. van Ree, C.C.D.F.; van Beukering, P.J.H.; Boekestijn, J. Geosystem services: A hidden link in ecosystem management. Ecosyst. Serv. 2017, 26, 58-69. [CrossRef]

15. Alahuhta, J.; Ala-Hulkko, T.; Tukiainen, H.; Purola, L.; Akujärvi, A.; Lampinen, R.; Hjort, J. The role of geodiversity in providing ecosystem services at broad scales. Ecol. Indic. 2018, 91, 47-56. [CrossRef]

16. Gray, M.; Gordon, J.E.; Brown, E.J. Geodiversity and the ecosystem approach: The contribution of geoscience in delivering integrated environmental management. P. Geologist. Assoc. 2013, 124, 659-673. [CrossRef]

17. da Garcia, M.G.M. Ecosystem services provided by geodiversity: Preliminary assessment and perspectives for the sustainable use of natural resources in the coastal region of the state of São Paulo, Southeastern Brazil. Geoheritage 2019, 11, 1-10. [CrossRef]

18. Reynard, E.; Perret, A.; Bussard, J.; Grangier, L.; Martin, S. Integrated approach for the inventory and management of geomorphological heritage at the regional scale. Geoheritage 2016, 8, 43-60. [CrossRef]

19. Brilha, J. Inventory and quantitative assessment of geosites and geodiversity sites: A review. Geoheritage 2016, 8, 119-134. [CrossRef]

20. Kubalíková, L. Geomorphosite assesment for geotourism purposes. Czech J. Tour. 2013, 2, 80-104. [CrossRef]

21. Štrba, L.; Rybár, P.; Baláž, B.; Molokáč, M.; Hvizdák, L.; Kršák, B.; Lukáč, M.; Muchová, L.; Tometzová, D.; Ferenčíková, J. Geosite assessments: Comparison of methods and results. Curr. Issues Tour. 2015, 18, 496-510. [CrossRef]

22. Zwoliński, Z.; Najwer, A.; Giardino, M. Methods for assessing geodiversity. In Geoheritage: Assessment, Protection, and Management; Reynard, E., Brilha, J., Eds.; Elsevier: Amsterdam, The Netherlands, 2018; pp. 27-52. [CrossRef]

23. Serrano, E.; Ruiz-Flaño, P. Geodiversity: A theoretical and applied concept. Geogr. Helv. 2007, 62, 140-147. [CrossRef]

24. Pereira, D.; Pereira, P.; Brilha, J.; Santos, L. Geodiversity assessment of Parana state (Brazil): An innovative approach. Environ. Manag. 2013, 52, 541-552. [CrossRef]

25. Zwoliński, Z.; Stachowiak, J. Geodiversity map of the Tatra national park for geotourism. Quaest. Geogr. 2012, 31, 99-107. [CrossRef]

26. Pellitero, R.; González-Amuchastegui, M.; Ruiz-Flaño, P.; Serrano, E. Geodiversity and geomorphosite assessment applied to a natural protected area: The Ebro and Rudron Gorges natural park (Spain). Geoheritage 2011, 3, 163-174. [CrossRef]

27. Silva, J.; de, P.; Rodrigues, C.; Pereira, D.I. Mapping and analysis of geodiversity Indices in the Xingu river Basin, Amazonia, Brazil. Geoheritage 2015, 7, 337-350. [CrossRef]

28. Dunlop, L.; Larwood, J.G.; Burek, C.V. Geodiversity Action Plans-A Method to Facilitate, Structure, Inform and Record Action for Geodiversity. In Geoheritage: Assessment, Protection, and Management; Reynard, E., Brilha, J., Eds.; Elsevier: Amsterdam, The Netherlands, 2018; pp. 53-65. [CrossRef]

29. Allan, M. Toward a Better Understanding of Motivations for a Geotourism Experience: A Self-Determination Theory Perspective. Ph.D. Thesis, Edith Cowan University, Perth, Australia, 2011.

30. Cheung, L.; Fok, L.; Fang, W. Understanding geopark visitors' preferences and willingness to pay for global geopark management and conservation. J. Ecotour. 2014, 13, 35-51. [CrossRef]

31. Allan, M.; Dowling, R.K.; Sanders, D. The motivations for visiting geosites: The case of crystal cave, Western Australia. Geo. J. Tour. Geosites 2015, 16, 142-153.

32. Štrba, L.; Kršák, B.; Sidor, C. Some comments to geosite assessment, visitors, and geotourism sustainability. Sustainability 2018, 10, 2578. [CrossRef]

33. Helgadóttir, G.; Sigurðardóttir, I. The riding trail as geotourism attraction: Evidence from Iceland. Geosciences 2018, 8, 376. [CrossRef]

34. Štrba, L. Analysis of criteria affecting geosite visits by general public: A case of Slovak (geo)tourists. Geoheritage 2019, 11, 291-300. [CrossRef]

35. Garavaglia, V.; Diolaiuti, G.; Smiraglia, C.; Pasquale, V.; Pelfini, M. Evaluating tourist perception of environmental changes as a contribution to managing natural resources in Glacierized areas: A case study of the Forni Glacier (Stelvio national park, Italian Alps). Environ. Manag. 2012, 50, 1125-1138. [CrossRef]

36. Avelar, S.; Mansur, K.; Anjos, S.C.; Vasconcelos, G.F. Community perceptions for geoconservation of a Coastal area in Rio de Janeiro, Brazil. Geoheritage 2015, 7, 275-283. [CrossRef] 
37. Martins, B.; Pereira, A. Residents' perception and assessment of geomorphosites of the Alvão-Chaves region. Geosciences 2018, 8, 381. [CrossRef]

38. Gilíková, H.; Hladil, J.; Bubík, M.; Buriánek, D.; Havíř, J.; Hrdličková, K.; Konečný, F.; Kociánová, L.; Dvořák, I.J.; Černý, J. Vysvětlivky k Základní Geologické Mapě České Republiky [Explanations to the Basic Geological Map of the Czech Republic] 1:25 000 24-413 Mokrá-Horákov; Český geologický ústav Praha: Prague, Czech Republic, 2010.

39. Müller, P.; Novák, Z. Geologie Brna a Okolí [Geology of Brno and its Surroundings]; Český geologický ústav Praha: Prague, Czech Republic, 2000.

40. Central Nature Conservation List. 2019. Available online: https://drusop.nature.cz/portal/ (accessed on 5 January 2021).

41. Likert, R.A. Technique for the measurement of attitudes. Arch. Psychol. 1932, 140, 5-55.

42. Act n. 114/1992 Coll. on Nature Conservation and Landscape Protection. Available online: https://www.zakonyprolidi.cz/cs/ 1992-114 (accessed on 23 December 2020).

43. Brilha, J. Geoconservation and protected areas. Environ. Conserv. 2002, 29, 273-276. [CrossRef]

44. Cílek, V. Geodiverzita. Vesmír 2000, 79, 95-97.

45. Ložek, V. Biodiverzita, ekofenomény a geodiverzita. Vesmír 2000, 79, 97-98.

46. Cílek, V. Geodiverzita-Opomíjený aspekt ochrany př́rody a Krajiny (Geodiversity-Neglected aspect of landscape and nature conservation). Zprávy o Geologických Výzkumech v Roce 2001, 2002, 13-15.

47. Joyce, E.B. Geomorphological Sites and the New Geotourism in Australia; Geological Society of Australia: Melbourne, Australia, 2006.

48. Szabó, J. Anthropogenic geomorphology: Subject and system. In Anthropogenic Geomorphology: A Guide to Man-Made Landforms; Szabó, J., Dávid, L., Lóczy, D., Eds.; Springer: Amsterdam, The Netherlands, 2010; pp. 3-12.

49. Szabó, J.; Dávid, L.; Lóczy, D. Anthropogenic Geomorphology: A Guide to Man-Made Landforms; Springer: Amsterdam, The Netherlands, 2010.

50. Ruban, D.A. Quantification of geodiversity and its loss. P. Geologist. Assoc. 2010, 121, 326-333. [CrossRef]

51. Pereira, P.; Pereira, D.; Alves, M. Geomorphosite assessment in Montesinho natural park (Portugal). Geogr. Helv. 2007, 62, 159-168. [CrossRef]

52. UNESCO. Convention Concerning the Protection of the World Cultural and Natural Heritage; UNESCO: Paris, France, 1972.

53. Pereira, P.; Pereira, D. Methodological guidelines for geomorphosite assessment. Géomorphologie 2010, 16, 215-222. [CrossRef]

54. Cave Administration of the Czech Republic (Správa jeskyní České republiky). Jeskyně a Krasová Území ČR [Caves and Karst Areas in the Czech Republic]. Available online: https:/ /administration.caves.cz/kras-a-jeskyne (accessed on 5 January 2021).

55. Mao, Y.; Robinson, A.M.; Dowling, R. Potential geotourists: An Australian case study. J. Tour. 2009, X, 71-80.

56. Ruban, D.A.; Sallam, E.S.; Ermolaev, V.A.; Yashalova, N.N. Aesthetic value of colluvial blocks in geosite-based tourist destinations: Evidence from SW Russia. Geosciences 2020, 10, 51. [CrossRef]

57. Kirilova, K.; Fu, X.; Letho, X.; Cai, L. What makes a destination beautiful? Dimensions of tourist aesthetic judgment. Tour. Manag. 2014, 42, 282-293. [CrossRef]

58. Dowling, R.K. Geotourism's global growth. Geoheritage 2011, 3, 1-13. [CrossRef] 